\title{
Demanio, obra pública y servicio público en el abastecimiento de aguas a la población: el problema de la caducidad por término de las concesiones en la materia
}

\author{
Marcos Vaquer Caballería \\ Profesor Titular de Derecho Administrativo \\ Universidad Carlos III de Madrid
}

SUMARIO: I. PLANTEAMIENTO. II. LA CONFIGURACIÓN HISTÓRICA DEL ABASTECIMIENTO DE AGUAS A LA POBLACIÓN COMO SERVICIO PÚBLICO. III. LA ESENCIAL UNIDAD DE LA CATEGORÍA DE LAS CONCESIONES ADMINISTRATIVAS. IV. LA TEMPORALIDAD COMO NOTA CARACTERÍSTICA DE LAS CONCESIONES ADMINISTRATIVAS EN GENERAL Y, EN PARTICULAR, DE LAS CONCESIONES PARA ABASTECIMIENTO DE AGUAS A POBLACIONES. V. LA RETROACTIVIDAD DE LA REDUCCIÓN DE LOS PLAZOS CONCESIONALES OPERADA POR LA LEGISLACIÓN SOBRE RÉGIMEN LOCAL DE LOS AÑOS 50 DEL SIGLO XX. VI. LA SERVICIALIDAD DEL DERECHO DE COSAS A LA FUNCIÓN QUE ÉSTAS CUMPLEN EN GENERAL Y, EN PARTICULAR, EN EL CASO DE LAS AFECTAS AL SERVICIO PÚBLICO: REVERSIÓN DE OBRAS Y REVISIÓN DE CONCESIONES DEMANIALES. VII. LA NATURALEZA Y LOS EFECTOS DE LA CADUCIDAD DE LA CONCESIÓN A SU VENCIMIENTO.

\section{PLANTEAMIENTO}

Durante la Restauración monárquica de las últimas décadas del siglo XIX se construyó - aprovechando en ocasiones materiales del periodo isabelino- un importante edificio legislativo sobre ejecución de obras públicas y uso del dominio público en general y, en especial, el aplicable a las aguas y sus aprovechamientos. La Ley de Obras Públicas de 1877 y la Ley de Aguas de 1879 son exponentes de la solidez de dicho edificio, en el que se integran también la de ferrocarriles asimismo de 1877, la de expropiación de 1879 o la de puertos de $1880^{1}$, por ejemplo. La primera de todas las citadas nunca ha sido formalmente derogada hasta ahora ${ }^{2}$ y la segunda sólo lo fue en 1985, cuando llevaba más de un siglo vigente, pese a lo

\footnotetext{
${ }^{1}$ Ésta y la de Aguas mencionada de 1879 resultan de la segregación de la predecesora Ley de Aguas de 1866.

${ }^{2}$ La reciente Ley 13/2003, de 23 de mayo, reguladora del contrato de concesión de obras públicas, ha derogado expresamente sus artículos 53 a 105 y 111.
} 
cambiante del contexto socio-económico en que hubo de ser aplicada ${ }^{3}$. A ellas tendremos que hacer reiteradas referencias.

En el periodo histórico a que nos referimos se empezaban a sentir en España los procesos de industrialización y de concentración urbana, que se acelerarían notablemente en la primera mitad del siglo xx y revolucionarían los usos del agua, acrecentando la percepción de su valor. El servicio de abastecimiento domiciliario de aguas (y las infraestructuras de canalización que precisa) se estaba todavía implantando y muchos eran los Municipios que carecían de él y así han seguido mucho después ${ }^{4}$. Como se verá, el servicio se irá extendiendo y concediendo al amparo de la legislación citada que es, al menos formal y aparentemente, una legislación de bienes y de obras antes que de servicio público, donde la concesión de éste a tarifa aparece como contraprestación que la Administración ofrece a la concesionaria por su financiación de las obras precisas para prestarlo, situación que se prolongó hasta que la legislación local de la Dictadura de Primo de Rivera formalizó su positivización como tal servicio público, dotándolo de un régimen cabal y específico. Muchas son las concesiones de obras y del servicio mismo otorgadas entre medias de ambas generaciones de leyes y mucha la confusión generada desde entonces sobre el régimen jurídico que les era aplicable, hasta el punto de que algunos de dichos títulos siguen ejecutándose hoy, las más de las veces aprovechando los silencios y ambigüedades del título mismo en punto a la naturaleza y duración de la relación por él trabada entre Ayuntamiento y empresa prestadora. La abundante jurisprudencia dictada en la materia ofrece testimonio de ello.

En este trabajo se estudiará el concreto problema del término de las concesiones para abastecimiento de aguas a la población ${ }^{5}$, que interesa no

\footnotetext{
${ }^{3}$ A pocos años de cumplirse el siglo de vigencia de la Ley de 1866-1879, Don Luis JoRDANA DE PozAs todavía la ponderaba afirmando que «toda la Ley está saturada de sentido jurídico» y calificándola de «tan acertada y fecunda», pese a propugnar su reforma "porque durante la última centuria todo lo que se refiere al agua y a sus aplicaciones ha sufrido cambios mayores que en los mil años que precedieron» (El Derecho español de aguas y la oportunidad de su revisión, Madrid, Real Academia de Jurisprudencia y Legislación, 1962, pp. 21, 54 y 61).

${ }^{4}$ Las sucesivas disposiciones históricas del siglo xx sobre auxilios del Estado a los Municipios para acometer las obras correspondientes nos ilustran sobre lo penoso y prolongado de este proceso.

${ }^{5}$ Para un estudio in extenso de este servicio, pueden verse Francisco Delgado Piqueras, «El abastecimiento a poblaciones en la Ley de Aguas. Análisis para una posible reforma», Revista de Administración Pública, n. ${ }^{\circ}$ 145, enero-abril 1998, pp. 305-328; Antonio EmBID IruJo, «Los servicios públicos del agua: su problemática jurídica con atención especial al abastecimiento y la depuración de las aguas residuales», en E. Malaret GarCía, dir., Régimen jurídico de los servicios públi-
} 
tanto en sí mismo, cuanto por la luz que puede ofrecer para hacer alguna reflexión más general sobre la categoría de las concesiones administrativas y el entramado que en ella se da entre bienes, obras y servicios, del que el caso que nos ocupa es paradigmático.

\section{LA CONFIGURACIÓN HISTÓRICA DEL ABASTECIMIENTO DE AGUAS A LA POBLACIÓN COMO SERVICIO PÚBLICO}

El objeto de los actos y contratos a que me he referido en el apartado anterior suele ser mixto, por comprensivo de obras públicas (las de canalización precisas) y del servicio a cuya prestación están destinadas dichas obras (el suministro domiciliario del agua), como es habitual que ocurra en las concesiones de servicios públicos. En efecto, para los servicios locales establece el artículo 114.2 del Reglamento de Servicios de las Corporaciones Locales (aprobado por Decreto de 17 de junio de 1955) que la concesión puede comprender «el mero ejercicio del servicio público cuando no requiera obras o instalaciones permanentes o estuvieren ya establecidas» o alternativamente «la construcción de una obra o instalación y la subsiguiente gestión del servicio a que estuvieren afectas», eventualidad esta última que también prevé el artículo 157, letra a), del vigente Texto Refundido de la Ley de Contratos de las Administraciones Públicas (aprobado por Real Decreto Legislativo 2/2000, de 16 de junio).

Ahora bien, el encaje de un contrato de tales características en alguna o algunas de las categorías jurídicas propias de nuestro ordenamiento jurídico vigente no es sencillo, pues constituye un ejercicio de anacronismo. Y sin embargo es necesario para dilucidar el régimen jurídico actual de la relación con él trabada.

cos, Madrid, Consejo General del Poder Judicial, 1997, pp. 419-485; José Antonio GARCía DE CocA, «El servicio público local de abastecimiento de agua potable, saneamiento y depuración. Nuevas tendencias, en especial su gestión indirecta», en F. Sosa Wagner, coord., El Derecho Administrativo en el umbral del siglo XXI. Homenaje al Profesor Dr. D. Ramón Martín Mateo, T. I, Valencia, Tirant lo Blanch, 2000, pp. 629-691; Juan Francisco Mestre Delgado, «El servicio público de distribución de aguas», en S. MuÑoz Machado, dir., Tratado de Derecho municipal, T. II, 2. a ed., Madrid, Cívitas, 2003, pp. 1647-1669; y Andrés Molina GiméNEZ, El servicio público de abastecimiento de agua en poblaciones: el contexto liberalizador, Valencia, Tirant lo Blanch, 2001. Sobre su historia, Juan Manuel Matés BARCO, Cambio institucional y servicios municipales. Una historia del servicio público de abastecimiento de agua, Granada, Comares, 1998. Sobre las competencias, Fernando SAINZ Moreno, «Competencias en materia de abastecimiento de agua y saneamiento», en F. Sosa WAGNER, coord.., El Derecho Administrativo ..., cit., T. II, pp. 19331947. Y sobre los problemas de su organización, en particular en Madrid, resulta del mayor interés el estudio de Martín Bassols Coma, «Abastecimiento de aguas y planeamiento metropolitano: el estatuto orgánico del Canal de Isabel II», RAP, n..$^{\circ}$ 76, enero-abril 1975, pp. 357-399. 
Es significativo, a este respecto, que la Ley Municipal de 20 de agosto de 1870 todavía no consagrara al abastecimiento de aguas como un servicio municipal, aunque sí atribuía en su artículo 67 a la exclusiva competencia de los Ayuntamientos el «surtido de aguas» o los «lavaderos», que eran infraestructuras mucho más comunes en la época, cuando, como decimos, todavía el abastecimiento de agua a la población se prestaba en muchos casos uti universi, no uti singuli como es propio de los servicios públicos en sentido estricto.

Sin embargo, y aunque en la legislación decimonónica no sólo los aprovechamientos de las aguas sino también éstas podían ser privadas, es lo cierto que «los trabajos relativos al régimen, aprovechamiento y policía de las aguas» en general ya tenían para el artículo 1 de la Ley de Obras Públicas de 13 de abril de 1877 (en adelante, LOP) la consideración de tales obras públicas, que más en particular su artículo $6.2^{\circ}{ }^{\circ}$ ponía a cargo de los Municipios «las obras de abastecimiento de aguas de las poblaciones» $\mathrm{y}$, en consecuencia, su artículo 11 atribuía a la Administración municipal conocer «del abastecimiento de aguas a las poblaciones, en lo tocante a la construcción de las obras o a la concesión de las mismas a empresas particulares». Este último inciso trae a su vez causa de la regla general de la Ley enunciada en su artículo 53, según la cual las obras públicas pueden ser ejecutadas por la Administración titular o, alternativamente, «los particulares y compañías podrán también construir y explotar obras públicas destinadas al uso general (...) mediante concesiones que al efecto se les otorguen».

Pues bien, según se fue implantando el servicio domiciliario de abastecimiento de aguas, resulta lógico que a él se aplicara el mismo régimen: consideración de la obra de infraestructura como una obra pública y del servicio como un servicio público, puesto asimismo bajo la competencia del Municipio, sin perjuicio de su prestación por privados. Esto último para hacer posible el ejercicio de la mencionada competencia sin merma de la débil hacienda pública: el particular, erigido en concesionario de la Administración, financiaba la obra y la gestión misma del servicio, viéndose retribuido de los usuarios mediante la percepción de una tarifa convenida con aquélla. Así se vino haciendo con la implantación de nuevos servicios requeridos de inversiones infraestructurales como el ferrocarril o el abastecimiento de aguas.

Luego, aunque no proclamado como tal, podemos afirmar que el abastecimiento de aguas a la población ya era concebido como un servicio público: de ahí que el artículo 169 de la Ley de Aguas de 13 de junio de 1879 (en adelante, referida también como LA 1879), al hilo justamente de 
la regulación del aprovechamiento de las aguas públicas para el abastecimiento de poblaciones, previera que «se fijará en la misma concesión la tarifa de precios que pueda percibirse por suministro del agua y tubería» $\mathrm{y}$ que su artículo 171 atribuyera a los Ayuntamientos «formar los reglamentos para el régimen y distribución de las aguas en el interior de las poblaciones» antes, en su caso, de la concesión del aprovechamiento del caudal correspondiente a una empresa y de forma tal que tales reglamentos (que fungen aquí como pliego de condiciones de la concesión) «una vez hecha la concesión, sólo podrán alterarse ... de común acuerdo entre el Ayuntamiento y el concesionario». Como advirtiera José Antonio GARCÍA-TrEvIJANO, «en la Ley española hay cierta interferencia entre la concesión demanial y la concesión de servicios al regular la concesión para abastecimiento de poblaciones» ${ }^{6}$. La cosa y la actividad se condicionan recíprocamente, e interferían cruzadamente sus regímenes jurídicos, en efecto, por más que la concesión de la primera fuera estatal y la competencia sobre el segundo fuera municipal.

Aunque no se encuentre, en suma, una publicatio expresa del servicio en la legislación de la época, ésta puede entenderse implícita en el régimen que otorga el ordenamiento de la Restauración a las concesiones de aguas y de las obras afectas al mismo, hasta el punto de poder concebir a éstas ya entonces como meros elementos o aspectos instrumentales de la concesión del servicio cuando de la concesión de aguas para abastecimiento de la población se trataba. En las autorizadas palabras de Eduardo GARCía DE ENTERRÍA, «la circunstancia de la afección de esas concesiones a una actividad de servicio público no sólo permite, sino que fuerza a una consideración accesoria de cada concesión en relación con el conjunto del servicio que trata de atenderse, que es lo que se destaca sustantivamente e impone su régimen al conjunto de elementos afectos» ${ }^{7}$.

En la literatura científica de la época se observan claras trazas de esta concepción, así como también de su evolución. Ya en 1904, GASCón Y Marín trata al abastecimiento de aguas como uno de los primeros servicios municipalizados en diversos países de Europa y reflexiona acerca de las ventajas e inconvenientes de la opción por la municipalización ${ }^{8}$

\footnotetext{
${ }^{6}$ José Antonio García-Trevijano Fos, «Caducidad de concesiones hidráulicas», RAP, n. ${ }^{\circ}$ 16, enero-abril 1955, p. 266.

${ }^{7}$ Eduardo García de EnTERRía, «El problema de la caducidad de las concesiones de aguas públicas y la práctica de las concesiones en cartera», $R A P$, n. $^{\circ} 17$, mayo-agosto 1955, p. 281.

${ }^{8}$ José Gascón Marín, Municipalización de servicios públicos, Madrid, Librería General de Victoriano Suárez, 1904, pp. 139 y ss.
} 
(entendida como la gestión directa de un servicio por el Municipio ${ }^{9}$ ) frente a las opciones del «sistema de empresa privada» y el de «concesión del servicio a particular» ${ }^{10}$. Y es que la concepción del abastecimiento de aguas como servicio público (a gestionar directa o indirectamente por concesionario) no es que pudiera concurrir, sino que directamente alternaba con su establecimiento como una actividad de libre empresa, aunque sometida a la intervención municipal ${ }^{11}$, al amparo de la indefinición legal sobre su naturaleza. Más tarde, y más rotundamente, Recaredo FERNÁNDEZ DE Velasco no dudará ya en tratar a las concesiones de aguas para abastecimiento de poblaciones de la LA 1879 - a todas ellas- como concesiones de servicio público y para ello acude, como el anterior autor citado, a la doctrina de los «los monopolios de hecho, es decir, aquellos que no se basan en una disposición de la ley, ni se procuran de una manera reflexiva. Aparecen principalmente en las Administraciones municipales, desde que a mediados del siglo xix se comenzó a aplicar el maquinismo a los servicios comunales, como los tranvías, gas, electricidad, aguas; servicios que ocupan la vía pública, bien por la superficie, bien por el subsuelo, pero que impiden la multiplicación de estas especies de servicios» ${ }^{12}$.

Entre la obra de uno y otro autor citados se alza un hito en nuestro Derecho de los servicios públicos. Nos referimos a las reformas de la Dictadura de Primo de Rivera. En primer lugar, el Estatuto Municipal de 8 de marzo de 1924 incluía en su artículo 150.9..$^{\circ}$ el abastecimiento de aguas entre los servicios «de la exclusiva competencia de los Ayuntamientos» y su artículo 170 habilitó expresamente para municipalizar con carácter de monopolio el servicio de abastecimiento de aguas. Aunque el Estatuto no proclamara expressis litteris al abastecimiento como servicio público, resulta ya manifiesta su concepción como tal y, en consecuencia, el Reglamento de Obras, Servicios y Bienes Municipales aprobado por Real Decreto de 14 de julio de 1924 se ocupó de regular en sus artículos 77 a 79 su concesión por los Municipios a empresas privadas.

\footnotetext{
9 «Implica la municipalización de servicios públicos el ejercicio directo de los mismos por los comunes». Últ. op. cit., p. 21.

${ }^{10}$ Ibidem, p. 143.

11 Todavía en 1949, GAY de Montellá y C. Massó Escofet seguían afirmando que la legislación española permitía dos sistemas alternativos de explotación del servicio: el de municipalización (por cualquiera de sus modalidades de gestión directa o indirecta) y el que llaman de «régimen libre, o sea la explotación del servicio de abastecimiento por Empresas o particulares propietarios de caudales de concesiones públicas, o de manantiales de propiedad», sujeto en todo caso a la «intervención y vigilancia sanitaria del Ayuntamiento» (Tratado de la legislación de aguas públicas y privadas, 2. ${ }^{\mathrm{a}}$ ed., Barcelona, Bosch, pp. 304 y 305).
}

12 Recaredo Fernández de Velasco, Los contratos administrativos, Madrid, 1927, pp. 258-259. 
Desde la óptica complementaria de la competencia estatal, el Real Decreto de 12 de abril de 1924 declaró ya en su artículo $1 .^{\circ}$ "servicios públicos los suministros de energía eléctrica, agua y gas a los abonados de las Empresas de distribución, correspondiendo al Ministerio de Trabajo, Comercio e Industria la reglamentación de tales servicios para garantía de la seguridad e intereses públicos, sin perjuicio de las demás intervenciones que puedan corresponder a otros Departamentos, a las Provincias y al Municipio sobre las concesiones y contratos administrativos». Pero lo que más interesa a nuestros efectos es que era voluntad inequívoca de la medida, además, la de novar las concesiones y autorizaciones preexistentes, para adaptarlas al régimen propio de un servicio público, puesto que su artículo 2..$^{\circ}$ prescribió que «a partir de la publicación de este Decreto todas las Empresas de distribución de energía eléctrica, agua y gas que disfruten de concesiones o autorizaciones administrativas del Estado, Provincias o Municipios y las que ocupen con las instalaciones terrenos de dominio público o del Estado, Mancomunidades, Provincias y Municipios, quedan obligadas a efectuar el suministro a todo abonado que lo solicite en tanto tenga medios técnicos para ello» $y$, de conformidad con su artículo $3 .^{\circ}$, a hacerlo «a los precios fijados en tarifas aprobadas por la Administración pública» las cuales nunca pueden ser superiores a los límites fijados en las concesiones, en su caso. Las resistencias y dudas interpretativas no debieron ser pocas, pues todavía por Orden del Ministerio de Agricultura de 3 de octubre de 1935 se declararía que todas las cláusulas de los Reglamentos de agua por que se rigieran las Empresas suministradoras que estuvieran en contradicción con el Real Decreto de 1924 se considerarían nulas y carentes de fuerza para obligar y debían desaparecer de dichos Reglamentos.

Por último, el Reglamento de Sanidad Municipal, aprobado por Real Decreto-Ley de 9 de febrero de 1925, proclamaba «obligación primordial de los Ayuntamientos proveer a las poblaciones de agua potable por su composición química y su pureza bacteriológica, y en suficiente cantidad para las necesidades de la vida». Con esta batería de disposiciones podemos entender culminado el proceso legislativo descrito y definitivamente cristalizada la concepción del abastecimiento de aguas como servicio público.

En efecto, como la mayoría de los demás incluidos en el citado artículo 170 del Estatuto de 1924 (de suministro de electricidad, alcantarillado, limpieza de calles y recogida y aprovechamiento de residuos domiciliarios, etc.), el de abastecimiento de aguas a la población ha constituido desde entonces un típico servicio público municipal, hoy además calificado como servicio esencial, reservado ex lege y de establecimiento y pres- 
tación obligatorios para todos los Municipios [artículos 86.3 y 26.1.a), respectivamente, de la Ley 7/1985, de 2 de abril, reguladora de las Bases del Régimen Local, en adelante, LBRL] ${ }^{13}$.

Por todas las razones aducidas, podemos concluir que ya los contratos celebrados bajo la vigencia de la Ley de Aguas de 1879 que tenían por objeto el otorgamiento de título suficiente para ejecutar las obras necesarias y prestar el servicio de abastecimiento de aguas a la población, comoquiera que se denominaran y calificaran, constituyen - cuando menos en el marco legal sobrevenido desde la Dictadura de Primo de Rivera- concesiones de un servicio público. Confirma esta interpretación la jurisprudencia del Tribunal Supremo, quien primero calificó como público al servicio apoyándose en la tipificación legal como obras públicas de las necesarias para su implantación: ya en una Sentencia de 22 de febrero de 1913, afirmó que «el abastecimiento de las poblaciones es un servicio público trascendental que se realiza a merced de obras costosas, comprendidas como de índole municipal en el art. $6 .^{\circ}$ de la Ley de 13 de abril de 1877 ». Más tarde, la misma doctrina podría ser mantenida y apoyada en una base legal más sólida: la Sentencia de 7 de diciembre de 1970 (R.Ar. 197015380) deja sentado que «si bien el concepto de servicio público de abastecimiento de aguas (...) no aparece definido de modo expreso en la legislación patria, no lo es menos que puede deducirse el criterio del legislador de lo que dispone el art. 1. ${ }^{\circ}$ del R.D.-Ley de 12 de abril de 1924» ${ }^{14}$. En similar línea, la Sentencia de 25 de noviembre de 1992 (R.Ar. 199219330) califica asimismo al servicio de abastecimiento de aguas a la población como «una actividad realizada por un particular que era material u objetivamente un servicio público» y le aplica las reglas correspondientes a la concesión del Reglamento de Servicios de las Corporaciones

\footnotetext{
${ }^{13}$ Donde la Ley básica se refiere sin más al abastecimiento de aguas, algunas Comunidades Autónomas han distinguido entre los servicios de aducción y de distribución de las aguas, con el objeto de atraer el primero hacia la competencia autonómica y sólo entender referida la reserva a la competencia municipal del segundo (y, en particular, el abastecimiento domiciliario: véanse las Leyes 17/1984, de 20 de diciembre, de abastecimiento y saneamiento de aguas de la Comunidad de Madrid, 4/1990, de 9 de marzo, de la Generalitat de Catalunya, de ordenación del abastecimiento de aguas en el área de Barcelona, y 1/1994, de 21 de febrero, del Principado de Asturias, sobre abastecimiento y saneamiento de aguas). Este último es, en cualquier caso, el que interesa a los efectos de este trabajo, por lo que no parece necesario detenerse en este matiz.

${ }^{14}$ Sigue la Sentencia desgranando los requisitos necesarios para apreciar tal condición: «por tanto, son requisitos fundamentales para que exista un servicio público de abastecimiento de aguas, los siguientes: a), suministro de agua por una determinada empresa, cuyo objeto sea, precisamente, la distribución de la misma; b), a personas ajenas a aquélla; c), que constituyan una cierta pluralidad indeterminada de usuarios; d), que se trate de una prestación regular y continua; e), que lo verifique la Administración pública u otra persona a la que se lo conceda dicha Administración, es decir, un concesionario; y f), que se realice por motivos y finalidades de interés público».
} 
Locales, pese a no estar calificado formalmente como concesión el contrato que lo había otorgado a una empresa privada.

Ahora bien, la conclusión que se acaba de alcanzar plantea otra cuestión previa, íntimamente vinculada al problema tratado de la consideración del abastecimiento como un servicio público o privado: podría alegarse que no son aquí aplicables las reglas legales de las concesiones, cuando la gestión del servicio de abastecimiento de aguas no fue otorgada mediante contrato de concesión sino mediante acto autorizatorio. Pero, como ya ha quedado dicho, la naturaleza de la relación jurídica trabada en cada caso y del negocio jurídico que la constituye debe prevalecer sobre la literalidad de éste. La dicción de los actos o contratos no siempre es concluyente. Tal cosa no debe sorprendernos: no sólo el lenguaje administrativo, sino incluso el legislativo ha utilizado históricamente con escaso rigor las nociones de concesión y autorización, aplicando en ocasiones el nomen legis de forma poco consistente con su nomen iuris, y sigue haciéndolo en la actualidad, hasta el punto de haber diluido notablemente la distinción entre ambos actos ${ }^{15}$.

Alimenta esta duda la existencia de alguna Sentencia del Tribunal Supremo que ha aplicado la institución de la autorización a la prestación por una empresa del servicio de abastecimiento de aguas ${ }^{16}$. Si así fuera, estaríamos ante una autorización de funcionamiento, categoría respecto de la que, por ejemplo, ya no cabría argüir la necesaria sujeción a término. Sin embargo, tal aplicación de la técnica autorizatoria es dogmáticamente problemática y, todo lo más, residual en la materia que nos ocupa, porque la autorización constituye idealmente un acto administrativo declarativo, por el que se comprueba la conformidad con el interés general (predeterminado en la ordenación aplicable) de una actividad de titularidad privada que proyecta realizar el interesado, a quien se habilita para ejercerla de forma no privativa o excluyente. Frente a ello, la regulación de la tarifa y demás extremos del servicio, la obligación de su prestación a cuantos interesados lo soliciten, el monopolio en el derecho concedido y su formalización en un contrato, habituales en los títulos que nos ocupan, no se compadecen con esta caracterización, dicho sea ello con la cautela que requiere la crisis por la que atraviesa la distinción entre concesiones y autorizaciones.

\footnotetext{
${ }^{15}$ Juan Alfonso SANTAMARÍA PASTOR llega por ello a afirmar que «las diferencias entre autorización y concesión son, hoy, meramente convencionales» (Principios de Derecho administrativo, vol. II, 3. ${ }^{\mathrm{a}}$ ed., Madrid, CEURA, p. 272).

${ }^{16}$ En este sentido, las SSTS de 15 de enero de 1971, R.Ar. 1971\152, y de 21 de junio de 1999, R.Ar. 199915375.
} 
Esta inadecuación de la técnica autorizatoria a una relación como la que nos ocupa ya se advierte perfectamente en la posterior sentencia de 29 de mayo de 2000 (R.Ar. 2000\5492), que circunscribe la doctrina de los fallos atrás aludidos a «casos aislados» en que «la prestación de los servicios en tal forma tenía un carácter anormal», porque con carácter general «cuando una empresa presta un servicio público a su riesgo y ventura, reteniendo la Administración municipal la titularidad del servicio y percibiendo la empresa una tarifa de los usuarios, la figura jurídica que se constituye es la de una concesión administrativa». De ahí que dicha sentencia se incline en el caso de autos por interpretar «los actos de las partes realizados a lo largo del tiempo de prestación del servicio», criterio que prima sobre la calificación formal dada en su momento al acto habilitante de la gestión indirecta del servicio y que le lleva a concluir que el mismo no constituye otra relación que la concesional.

\section{LA ESENCIAL UNIDAD DE LA CATEGORÍA DE LAS CONCESIONES ADMINISTRATIVAS}

Ya tenga por objeto un uso privativo de un bien de dominio público, la ejecución de una obra sobre el mismo o la gestión de un servicio cuya titularidad está reservada a la Administración, toda concesión es un título constitutivo de un derecho privativo (esto es, excluyente de la libre competencia con terceros) pero derivado (y, por ende, necesariamente contingente por su contenido y por su duración) a un sujeto para realizar una actividad originariamente reservada a la Administración, por la afectación de la misma, o de la cosa de que se vale, al uso o servicio público. Esta caracterización de la concesión administrativa permite, de un lado, diferenciarla ad extra de forma neta (aunque sólo ideal, como ya ha sido indicado) de la autorización (que supuestamente no constituye derecho alguno, sino que declara la legalidad del ejercicio de una actividad de titularidad privada; por ello mismo, además, lo hace de forma no privativa o excluyente). De otro lado, ad intra, reconoce unidad a la categoría de las concesiones administrativas, sin perjuicio del reconocimiento de sus variadas modalidades (concesión demanial, concesión de obra pública, concesión de servicio público) y sus correspondientes regímenes jurídicos diferenciados.

Esta unidad fue afirmada entre nosotros con autoridad por José Luis Villar Palasí hace medio siglo en su clásica voz «Concesiones administrativas» de la Nueva Enciclopedia Jurídica ${ }^{17}$, para quien «el progre-

${ }^{17}$ Ed. Seix, Tomo IV, pp. 684-770. 
so de cada forma específica de concesión ha ido esfumando esta comunidad genérica, mas es evidente que, pese a tales diferencias, no hay necesariamente que renunciar a la construcción de una idea unitaria, basada en la comunidad genérica y de génesis de las formas concesionales de la actualidad» ${ }^{18}$, construcción cuyas «grandes líneas» serían «el carácter personalísimo con la falta de transmisibilidad de la concesión, sin previa autorización; la caducidad por incumplimiento, la temporalidad concesional (...) y, finalmente, la reversión al extinguirse la concesión» ${ }^{19}$.

Pues bien, importa destacar aquí esta unidad esencial de la categoría concesional no ya por un prurito dogmático, sino porque nos encontramos en este trabajo ante negocios jurídicos mixtos, pues suelen tener por objeto obras y servicios públicos, consistentes estos últimos además en el suministro de un bien (el agua) de régimen habitualmente demanial. Para su estudio, como se verá, voy a tener en lo sucesivo muy presente metodológicamente la visión comprehensiva de las concesiones administrativas. Por lo demás, esta misma mixtura, que es bastante habitual, nos ilustra sobre los entreveramientos existentes entre las diversas modalidades de concesión y, en definitiva, ratifica la tesis sobre la unidad sistémica de la categoría que acabamos de defender. Pues la concesión de servicios públicos, ¿acaso no suele conllevar la concesión de derechos exclusivos de ocupación y uso de bienes demaniales y de ejecución de obras públicas sobre los mismos, que revierten a la Administración cuando lo hace el servicio?; la concesión de obra pública, ¿acaso no comprende asimismo la concesión demanial del suelo y demás bienes que se precise ocupar y usar privativamente?; y justificándose en fin el demanio por la afectación al uso o servicio público del bien, la concesión demanial, ¿acaso no tiene en ocasiones por objeto un uso de servicio público, como puede ocurrir precisamente con los aprovechamientos de aguas concedidos para el abastecimiento de poblaciones? De estas concurrencias y de la identidad esencial de la ratio de todas ellas se siguen, lógicamente, la compartición por todas de notas como la de la temporalidad, que nos ocupará a continuación, o la de la reversión, que lo hará algo más adelante, así como la necesidad de establecer algún tipo de orden o prelación en las relaciones entre ellas, allí donde concurren, que será asimismo objeto de un apartado posterior.

\footnotetext{
${ }^{18}$ Cit., p. 688.

${ }^{19}$ Ibidem, p. 689.
} 


\section{LA TEMPORALIDAD COMO NOTA CARACTERÍSTICA DE LAS CONCESIONES ADMINISTRATIVAS EN GENERAL Y, EN PARTICULAR, DE LAS CONCESIONES PARA ABASTECIMIENTO DE AGUAS A POBLACIONES}

Como hemos visto que observara Villar Palasí en su espléndido trabajo antes citado, una de las notas características de las concesiones administrativas cabalmente consideradas es la de su temporalidad o sujeción a plazo por imperio de la Ley. A ello aludía más atrás al referirme a la contingencia del derecho subjetivo constituido por toda concesión.

Porque si la concesión es una institución de equilibrio o balance entre responsabilidad pública e iniciativa privada, entre Estado y mercado en suma, que permite el juego de esta iniciativa dentro del marco de aquella responsabilidad o, en otros términos, habilita el ejercicio privado de una actividad (el uso de un bien, la ejecución de una obra, la prestación de un servicio) de titularidad pública, resulta natural que tenga una duración determinada. Nótese que me refiero aquí a las concesiones otorgadas a sujetos de Derecho privado y estatuto ordinario, porque las concesiones que operan en el plano interadministrativo (por ejemplo, las otorgadas por la Administración hidráulica a los Ayuntamientos para el abastecimiento de aguas a sus poblaciones) se rigen por una lógica diversa.

Por lo demás, decimos que la sujeción a término de las concesiones es natural, no esencial. En primer lugar, porque no han faltado en nuestra legislación y práctica administrativas las concesiones a precario, en las que su duración indefinida era compensada por la prerrogativa de la Administración de acordar su extinción en cualquier momento sin indemnización. En segundo lugar, porque no cabe afirmar, como a veces se ha pretendido, que la perpetuidad convertiría la concesión del uso de un bien público en una cesión o enajenación del bien mismo, o la concesión de la gestión de un servicio público en su privatización, atentando en ambos casos contra el principio de la inalienabilidad de la soberanía ${ }^{20}$. Eduardo GARCíA DE ENTERRía ya se ocupó de desmontar el «dogma de la reversión de concesiones», afirmando que «si todo ejercicio privado de funciones públicas se hace en nombre de la Administración y bajo su vigilancia, no existe en la concesión inicialmente enajenación ninguna de soberanía, por lo que tampoco es preciso asegurar su retorno posterior» ${ }^{21}$. A ello pode-

\footnotetext{
${ }^{20}$ Para una revisión de las diversas teorías sustentadoras del término de las concesiones, puede verse Juan Francisco Mestre Delgado, La extinción de la concesión de servicio público, Madrid, La Ley, 1992, pp. 23-39.

${ }^{21}$ Eduardo García de EnTERría, Dos estudios sobre la usucapión en Derecho Administrativo, 2. ${ }^{a}$ ed., Madrid, Tecnos, 1974, p. 73. El debate, sin embargo, no parece estar zanjado y se replanteó
} 
mos añadir que la reversión no es precisa, pero sí tradicional y además pertinente en la mayoría de las concesiones — debidamente planteada como «cláusula económica» ${ }^{22}$ — por razones de seguridad jurídica (art. 9.3 CE), favorecimiento de la libre competencia (principio ínsito en el derecho a la libertad de empresa, art. $38 \mathrm{CE}$, y expresamente aplicado a las empresas prestadoras de servicios de interés económico general por el art. 86.2 del Tratado de la Comunidad Europea), eficacia de las Administraciones públicas (art. 103.1 CE) y subordinación de toda la riqueza al interés general (art. 128.1 CE) en las que no es preciso extenderse aquí.

En consecuencia, no han faltado en nuestra legislación histórica concesiones a perpetuidad ${ }^{23}$, hasta que la vigente Ley de Patrimonio del Estado de 1964 (Texto Articulado aprobado por Decreto 1022/1964, de 15 de abril) sentara ya de forma general e improrrogable en su artículo 126 la duración máxima de cualesquiera concesiones o autorizaciones sobre el dominio público en noventa y nueve años y la regla según la cual «en ningún caso podrán otorgarse dichas concesiones o autorizaciones por tiempo indefinido», y un año después la Ley de Contratos del Estado (Texto Articulado aprobado por Decreto 923/1965, de 8 de abril) hiciera otro tanto en su artículo 64 respecto de las concesiones de servicios públicos.

justamente a propósito de la constitucionalidad de las concesiones perpetuas de aguas con ocasión de la promulgación de la LA 1985, cuya disposición transitoria primera sujetó a plazo de caducidad. Según el Tribunal Constitucional, en su Sentencia 227/2988 (F.J. 11. ${ }^{\circ}$ ), «los derechos de aprovechamiento privado a perpetuidad no son compatibles en el plano de la efectividad no puramente formal de las normas jurídicas, con los principios de inalienabilidad e imprescriptibilidad de los bienes de dominio público que el artículo 132.1 de la Constitución consagra» a lo que Sebastián Martín-Retortillo (Derecho de aguas, Madrid, Civitas, 1997, p. 262) replica que no hay tal incompatibilidad porque en las relaciones concesionales «el Estado (...) es en todo momento el señor del servicio, del bien cuyo aprovechamiento se otorga».

${ }^{22}$ García de Enterría, ult. op. cit., p. 78.

${ }^{23}$ Para las de aguas, pueden verse los artículos 159, 188 y 220 LA 1879. Y, sin embargo, hay que tener presente que el desarrollo legislativo posterior tendió a limitar la duración de alguna de dichas concesiones. Para ilustrarlo pueden verse, por ejemplo, el artículo 3 del Real Decreto de 14 de junio de 1921, sobre concesiones de aprovechamientos para fuerza motriz y usos industriales, o el artículo 11 del Decreto de 18 de junio de 1943, sobre concesiones de aprovechamientos de salto a pie de presa. Del mismo modo, si bien es cierto que, en palabras de Sebastián MarTínRetortillo (Aguas públicas y obras hidráulicas, Madrid, Tecnos, 1966, p. 419), «puede incluso afirmarse que en el momento de promulgarse la Ley [de Canales de Riego] de 1870 la perpetuidad de las concesiones era el régimen general entonces establecido para las concesiones de dominio público, en base a lo que establecía el artículo 5 del Decreto-Ley de 14 de noviembre de 1868 (...)» (la cursiva en el original), también hay que tener presente que este Decreto-Ley, por el que se establecían las bases generales para la nueva legislación de obras públicas, fue después sustituido por la Ley de 29 de diciembre de 1876, dictando nuevas bases, entre las que su artículo 11 ya establece la regla general del plazo máximo de 99 años, sólo exceptuable por ley. Es en desarrollo de estas últimas bases que se dictó la LOP 1877. 
En fin, más allá incluso de las excepciones legales al principio de la temporalidad de las concesiones, menudeó la práctica administrativa que las otorgaba por tiempo indefinido o incluso perpetuamente incumpliendo la Ley, para lo que a veces adoptó la veste de meras autorizaciones o permisos.

El Tribunal Supremo ha desplegado un considerable esfuerzo por interpretar, allí donde ha tenido ocasión, que las excepciones al principio de la temporalidad de las concesiones no eran en rigor tales, sino sólo aparente o nominalmente. Según esta doctrina, las que se contenían en las leyes, configuraban en realidad negocios distintos del concesional, y las recogidas en actos y contratos administrativos, debían interpretarse de conformidad con los plazos máximos legales, de forma que las cláusulas de duración indefinida no podían implicar perpetuidad sino mera indeterminación, y la perpetuidad, cuando era expresamente establecida, debía reputarse nula.

Todo ello sobre la base de una doctrina general esencialista según la cual «la concesión, toda concesión, ha de ser incardinada en la categoría conceptual de «negocio fijo», o «negocio de término esencial», lo que quiere decir que esta figura jurídica no es concebible en una dimensión temporal indefinida y que, más pronto o más tarde, la concesión ha de caducar» ${ }^{24}$. En consecuencia, el Alto Tribunal tiene afirmado por ejemplo que la perpetuidad está «en pugna con la propia esencia de las concesiones de dominio público, pues bienes de dominio y servicio públicos son los mercados municipales, y la de autorizaciones para ejercer una actividad privada sobre bien de dominio y servicio públicos, siempre de carácter temporal, sin que la perpetuidad pueda presumirse a falta de indicación expresa, ni la misma, de existir, pueda reputarse válida» ${ }^{25}$; que la «concesión a perpetuidad del lugar de enterramiento» hecha al amparo del Reglamento de Policía Mortuoria de 20 de julio de 1974 no era en propiedad una concesión de servicio público ni demanial ${ }^{26}$ y que las llamadas «concesiones de marismas» de la Ley de Puertos de 7 de mayo de 1880, cuyo artículo 55 permitía otorgar «sin pública licitación y a perpetuidad», tenían por objeto la desecación o el saneamiento de dichas marismas, cuyo cumplimiento producía por efecto su desafectación y conversión en bienes patrimoniales por lo que, en puridad de doctrina, tampoco eran verdaderas concesiones demaniales ${ }^{27}$.

\footnotetext{
${ }^{24}$ STS de 14 de julio de 1981, R.Ar. $1981 \backslash 3484$.

25 STS de 29 de abril de 1988, R.Ar. 198813291; en el mismo sentido, también sobre concesiones de puestos de venta en un mercado municipal, STS de 28 de mayo de 1986, R.Ar. 198614601.

${ }^{26}$ STS de 11 de octubre de 1999, R.Ar. 1999\7815.

${ }^{27}$ STS de 7 de febrero de 1984, R.Ar. 1984\782. La sentencia, en cambio, les atribuye de forma un tanto inopinada la condición de «concesiones de obra pública, de uso privado», al amparo de
} 
Por lo que hace concretamente a la concesión que tiene por objeto este trabajo, la Ley ya citada de Obras Públicas de 1877 y la Ley de Aguas de 1879 fijaban taxativa y coincidentemente en 99 años la duración máxima de las concesiones de obras públicas y de aprovechamiento especial de aguas públicas para el abastecimiento de poblaciones que se otorgasen a favor de particulares o empresas privadas (artículos 55 y 170, respectivamente).

Desde entonces, la evolución de la legislación aplicable a la duración de las concesiones en la materia ha constituido un zig-zag que, en todo caso, nunca ha abandonado la nota de su temporalidad. Tres décadas más tarde, la letra b) del artículo 173 del Estatuto Municipal de 1924, dejó a la autonomía de la voluntad de las partes pactar un «plazo mínimo de cinco años y máximo de veinte» para la concesión de la explotación de los servicios públicos municipales de su artículo 170, entre los que ya sabemos que se contaba el de abastecimiento de aguas.

Un tercer hito de esta evolución —-singularmente importante por la razón que se aducirá en el apartado siguiente- lo constituye la legislación de régimen local de los años 50 del siglo xx. Tanto el Reglamento de Contratación de las Corporaciones Locales de 1953 (artículo 10) como la Ley de Régimen Local de 1955 (art. 163) y el Reglamento de Servicios del mismo año (art. 115) fijaron en 50 años la duración máxima de las concesiones de los servicios públicos locales. La Ley de Contratos del Estado de 1965 (art. 64) y su Reglamento General de 1975 (art. 199) volvieron a ampliarla a 99 años. La Ley de Contratos de las Administraciones Públicas de 1995 (art. 158) la redujo de nuevo, esta vez a 75 años y, por fin hasta el momento, su modificación de 1999 y su Texto Refundido de 2000 lo han vuelto a hacer (art. 157 del TR), estableciendo el plazo máximo de 50 años para las concesiones de servicios públicos que incluyan la ejecución de obras públicas y 25 años para los restantes, excluidos los sanitarios. En todo caso, como afirma el último de los preceptos mencionados, el vigente en la actualidad, «el contrato de gestión de servicios públicos no podrá tener carácter perpetuo o indefinido».

\footnotetext{
lo previsto en los artículos 7, números 3, 4 y 5, 53 y 95 LOP 1877 y de conformidad con los precedentes jurisprudenciales que cita (puede verse, en particular, la prolija STS de 10 de noviembre de 1976, R.Ar. 1976\4941). En sede doctrinal, esta tesis había sido defendida por Luis MorELL OCAÑA, «La concesión de marismas y el artículo 126 de la Ley de Patrimonio del Estado», RAP, n. ${ }^{\circ}$ 68, mayo-agosto 1972, pp. 137 y ss., pero no para justificar su perpetuidad sino, bien al contrario, para concluir que su plazo de duración «no es otro que el señalado para la ejecución de las obras de desecación y saneamiento. Terminado dicho plazo, desaparece la relación concesional» (p. 176).
} 


\section{LA RETROACTIVIDAD DE LA REDUCCIÓN DE LOS PLAZOS CONCESIONALES OPERADA POR LA LEGISLACIÓN SOBRE RÉGIMEN LOCAL DE LOS AÑOS 50 DEL SIGLO XX}

Como se ha visto en el apartado anterior, la LOP y la LA 1879 fijaban en 99 años la duración máxima para las concesiones del aprovechamiento de aguas para el abastecimiento de las poblaciones y de las obras públicas a él afectas. Dicha duración máxima se ha visto modificada sucesivamente, evolución de la que ya sólo interesa retener aquí la legislación local de los años 50 del siglo pasado, que sabemos que fijaba el plazo máximo en 50 años.

Es cierto y sabido que la aplicación de las leyes a relaciones jurídicas consumadas antes de su entrada en vigor constituye un supuesto de retroactividad y, como tal, es excepcional y debe interpretarse estrictamente. Así resulta de lo dispuesto en los artículos 2.3 y 4.2 del Código civil. Ahora bien, el Tribunal Constitucional ya ha dejado sentado que es preciso distinguir entre esta retroactividad «auténtica», existente cuando se pretenden anudar efectos jurídicos a situaciones de hecho producidas con anterioridad a la norma y ya consumadas, y una retroactividad «impropia», consistente en afectar a situaciones jurídicas actuales y aún no concluidas ${ }^{28}$. Lo ha afirmado a propósito de la prohibición de retroactividad del artículo 9.3 de la Constitución, para entender que esta prohibición sólo opera plenamente respecto de la primera, mientras que la licitud o ilicitud de la segunda depende de una ponderación de bienes que tenga en cuenta ciertamente la seguridad jurídica, pero también las circunstancias del supuesto, el grado de retroactividad de la norma cuestionada, etc. Pero no puede ofrecer duda el que la misma doctrina y distinción nos ha de ser útil para interpretar y aplicar los preceptos antes citados del Código civil, a cuyos efectos también ha de ser tenida por menos odiosa la retroactividad impropia.

Pues bien, tanto la disposición transitoria 2. ${ }^{\mathrm{a}}$ del Reglamento de Contratación de las Corporaciones Locales de 9 de enero de 1953 como las transitorias 2. ${ }^{\mathrm{a}}$ y $4 .^{\mathrm{a}}$ del Reglamento de Servicios de las Corporaciones Locales de 17 de junio de 1955 prevén expresamente su aplicación a los servicios locales ya existentes y concedidos al tiempo de su entrada en vigor. Por su mismo sentido, podemos entender que se refieren sólo a aquéllos cuya concesión todavía no se hubiera extinguido en dicho

\footnotetext{
${ }^{28}$ Por todas, SSTC 6/1983, F.J. 3. ${ }^{\circ}$, 126/1987, F.J. 9. ${ }^{\circ}$, y 197/1992, de 19 de noviembre, F.J. 4. ${ }^{\circ}$.
} 
momento y, por tanto, que constituyen casos de retroactividad impropia. Aunque el primero de ellos matiza no obstante que dicha aplicación «a las cuestiones suscitadas respecto de los mismos» debe hacerse «sin menoscabo de los derechos adquiridos», aclara a continuación en la disposición transitoria 3. ${ }^{\mathrm{a}}$ que «no tendrán la consideración de derechos adquiridos para los licitadores y contratistas las situaciones derivadas de cláusulas o convenios cuya nulidad se declara en el presente Reglamento», siendo así que justamente su artículo $10 .^{\circ}$ declara «nulos los contratos de duración indeterminada o por más de cincuenta años».

El Reglamento de Servicios, más sencillamente, omite todo matiz sobre derechos adquiridos y prevé sin más su aplicación «a los servicios existentes en la actualidad para el régimen sucesivo de los mismos», lo que da pie para entender que, por su virtud, se produce ex lege la reducción a 50 años del plazo de las concesiones ya otorgadas y eficaces, cuando éste fuera originalmente superior.

Así se afirma desde luego en la sentencia del Tribunal Supremo de 31 de octubre de 1995 (R.Ar. 1995\7718), según la cual «el artículo 163.1, a) de la Ley de Régimen Local de 24 junio 1955 establecía que tanto en los casos de arrendamiento, como en los casos de concesión y empresa mixta el término del convenio nunca podría exceder de cincuenta años; término igualmente establecido en el artículo 10 del Reglamento de Contratación de las Corporaciones Locales de 9 enero 1953 y en el artículo 111.1 del Reglamento de Servicios de las Corporaciones Locales de 17 junio 1955. Esta normativa es aplicable a la Compañía de Aguas de (...) aunque su contrato fue otorgado en 1949, en virtud de la disposición transitoria segunda del Reglamento de Servicios antes citado y disposición transitoria segunda del Reglamento de Contratación, también citado antes», lo que sirve además al Alto Tribunal para establecer, después de advertir que en el caso de autos se había atribuido «al acuerdo municipal impugnado la reducción del plazo de la concesión del servicio; cuando tal reducción ha tenido lugar por ley y lo que hace el acuerdo del Ayuntamiento es una declaración en relación con la normativa que cita».

Pero es que, sobre la base de la aplicación retroactiva del corpus legislativo que comentamos, el Tribunal Supremo ha llegado a declarar no ya sólo la invalidez, sino la nulidad radical o de pleno Derecho de las cláusulas contractuales a él contrarias, pues «el carácter perpetuo es incompatible con la naturaleza de las concesiones y es radicalmente nula cualquier cláusula contraria al régimen de temporalidad concesional establecido en el artículo 115,4 de dicho Reglamento», en alusión al de Servicios de las 
Corporaciones Locales ${ }^{29}$. Podría tratarse de ir más lejos aún, y defenderse la nulidad del entero contrato, sobre la base de una interpretación literal del citado artículo 10 del Reglamento de Contratos, en relación con sus disposiciones transitorias $2 .^{\mathrm{a}}$ y $3 .^{\mathrm{a}}$, e incluso sobre una interpretación finalista que considere esencial la duración por afectar a la causa misma del contrato, pero resulta más acorde con los principios de conservación de los actos administrativos y de confianza legítima la extensión de los efectos del vicio sólo a la cláusula o parte de ella que determine una duración superior a la máxima legal.

Por lo demás, podría discutirse si esta reducción por Ley sobrevenida de la duración de las concesiones de servicios locales constituye una expropiación del derecho del concesionario y, como tal, es indemnizable. Nada dicen al respecto los preceptos que la establecen, lo que puede ser interpretado como un rechazo implícito del legislador a tal hipótesis. Rechazo que vendría avalado hoy, además, por la doctrina sentada por el Tribunal Constitucional - aunque contestada por un sector de la doctrina ${ }^{30}$ - a propósito de la sujeción a nuevo plazo máximo de todas las concesiones demaniales (también las que eran antes perpetuas) operada por la disposición transitoria 1. ${ }^{a}$ de la Ley de Aguas de 1985. En su Sentencia 227/1988, de 29 de noviembre, afirma el Alto Tribunal que con ello «no puede decirse que se produzca una ablación de los mismos, ni siquiera parcial, a la que convenga el calificativo de expropiatoria, sino que se trata de una nueva regulación del contenido de aquellos derechos, que afecta, sin duda, a un elemento importante de los mismos, pero que no restringe o desvirtúa su contenido esencial».

\section{LA SERVICIALIDAD DEL DERECHO DE COSAS A LA FUNCIÓN QUE ÉSTAS CUMPLEN EN GENERAL Y, EN PARTICULAR, EN EL CASO DE LAS COSAS AFECTAS AL SERVICIO PÚBLICO: REVERSIÓN DE OBRAS Y REVISIÓN DE CONCESIONES DEMANIALES}

Obviamente, el que podríamos llamar «Derecho de cosas» (esto es, el universo formado por los diversos regímenes reales del ordenamiento, que contraponemos al «Derecho de personas» $\mathrm{u}$ ordenador de estatutos personales) nunca ha percibido a las cosas en sí, inmanentemente, sino transcendentemente por la utilidad que dichas cosas reportan a las personas (los

\footnotetext{
${ }^{29}$ STS de 28 de mayo de 1986, R.Ar. $1986 \backslash 4601$.

${ }^{30}$ Vid. Sebastián Martín-Retortillo, Derecho de aguas, cit., pp. 258-262.
} 
sujetos del Derecho). Las cosas son aprehendidas por el Derecho como bienes, esto es, como realidades portadoras de utilidad, de valor (tradicionalmente económico o patrimonial, hoy también cultural, por ejemplo). Hasta tal punto, que lo que determina el contenido de los derechos y las potestades de las personas sobre las cosas es la función que éstas cumplen para los diversos intereses de que aquéllas son titulares, singular, colectiva o socialmente. Hoy, ello queda explicitado con el máximo rango en nuestro Ordenamiento cuando la Constitución afirma en su artículo 33.2 que la función social de la propiedad delimita su contenido. Si así es en el Derecho privado, cuánto más en el público en general y administrativo en particular, donde todo está supeditado al interés general (art. 103.1 CE) y donde los bienes no entregados al tráfico jurídico ordinario sino a un régimen jurídico exorbitante, como es el del dominio público (art. 132 CE), lo son precisamente por estar afectados al uso o servicio público. Se comprende, pues, que dicho uso o servicio deba presidir el régimen de estos bienes por entero, que sólo se explica y viene determinado por su afectación a él. Todo derecho subjetivo sobre un bien demanial afectado a un servicio público, en consecuencia, debe entenderse subordinado al mejor funcionamiento de dicho servicio.

Pues bien, en materia de gestión de servicios públicos, existe un principio bien conocido e inapelable de orden público, como es el de la continuidad del servicio. Tanto más en los servicios de primera necesidad, como es el de abastecimiento de agua a la población, cuya cualificación como tal se refleja, por ejemplo, en el orden de prelación que le otorga el artículo 60.3.1. ${ }^{\circ}$ de la vigente Ley de Aguas (Texto Refundido aprobado por Real Decreto Legislativo 1/2001, de 20 de julio), como ya hiciera por demás su precedente artículo $160.1 .^{\circ}$ de la Ley de 1879 , o en la calificación que de él hace como servicio mínimo de prestación obligatoria en todos los Municipios el artículo 26.1.a) de la Ley reguladora de las Bases del Régimen Local.

Dicho principio inspira la regla según la cual la reversión del servicio al término del plazo de la concesión implica la reversión gratuita a la Administración titular del servicio de los bienes e instalaciones necesarios para la gestión del servicio. Así lo tiene establecido con rotundidad la Sentencia del Tribunal Supremo de 16 de junio de 1989 (R.Ar. 1989 44727), según la cual «el principio fundamental en esta materia (extinción del contrato por cumplimiento del plazo contractual) exige por razones inexcusables y relacionadas con la continuidad del servicio (como nota básica) la devolución de las obras e instalaciones precisas para que el servicio continúe prestándose con normalidad». Puede traerse también a colación la 
Sentencia de 29 de mayo de 2000 (R.Ar. 2000\5492), por haber sido dictada precisamente en materia de abastecimiento de aguas, y según la cual «es de esencia a la caducidad temporal de las concesiones de servicios públicos, por contra de su caducidad anticipada o rescate, la reversión gratuita a la Administración concedente. (...). El principio de que al extinguirse una concesión administrativa de servicio público deben revertir a la Administración los bienes e instalaciones necesarios para la prestación del servicio, que la empresa concesionaria ha debido amortizar durante el tiempo de duración de la concesión, es una consecuencia lógica de que la titularidad del servicio corresponde a la Administración y de que ésta, al extinguirse la concesión, debe continuar prestando dicho servicio, que en el caso de autos era un servicio público de primera necesidad (el suministro y abastecimiento de agua potable a la ciudad de Alzira y su término municipal).»

La reversión gratuita resulta aplicable, desde luego, cuando los bienes e instalaciones han sido amortizados o debían haberlo sido al tiempo de la extinción de la concesión por vencimiento de su plazo, como cabe presumir que ocurre en los casos que nos hemos planteado en este estudio en consideración al largo tiempo transcurrido desde la constitución de la concesión. Pero lo es además, siempre según la sentencia citada en último lugar y la STS de 7 de junio de 1988 (R.Ar. 1988\4599), incluso aunque dichas instalaciones e inversiones no estuvieran amortizadas.

Pues bien, de conformidad con la legislación reguladora de los servicios públicos, los bienes deben seguir la misma suerte que la actividad o servicio a que están afectados, suerte que no es otra que su reversión gratuita a la Administración titular del servicio, cuando se produce la caducidad del título habilitante de la gestión indirecta de este último. Así resulta con toda claridad de lo dispuesto en los artículos 115.2. ${ }^{\mathrm{a}}, 128.1 .4 .^{\mathrm{a}}$ y 137.1 del Reglamento de Servicios de las Corporaciones Locales y 164.1 de la Ley de Contratos de las Administraciones Públicas.

Concurre, por último, a favor de la interpretación que aquí se sostiene la propia legislación decimonónica de Aguas, pues incluso conforme a ella cabe sostener también el dominio público sobre las obras realizadas para la extracción y el abastecimiento de las aguas. Al aprovechamiento de las aguas públicas para el abastecimiento de poblaciones se refieren el artículo 160.1 y los artículos 164 a 171 de la Ley de Aguas de 1879. Y ya su artículo 170 prescribe que, transcurrido el plazo de la concesión, «quedarán todas las obras, así como la tubería, a favor del común de los vecinos». Y, en consonancia con ello, la Ley de Obras Públicas de 13 de abril de 1877 declara como ya se ha indicado en su artículo $1 .^{\circ}$ que son obras públicas 
«las que sean de general uso y aprovechamiento», incluyendo entre tales expresamente «los trabajos relativos al régimen, aprovechamiento y policía de aguas», y especifica después en su artículo $6 .^{\circ}$ que «son de cargo de los Municipios (...) 2. ${ }^{\circ}$ Las obras de abastecimiento de aguas de las poblaciones».

Por lo demás, esta supeditación de las cosas al servicio, que constituye su función, no rige en mi opinión sólo respecto de las infraestructuras u obras públicas, sino también para el propio caudal de agua destinado a la prestación del servicio. Hay entre el bien, las obras y el servicio una comunidad de destino, que viene marcada por este último.

Cuando dicho caudal haya sido objeto de una concesión demanial de aprovechamiento de aguas públicas para el abastecimiento de poblaciones, resulta lógico prever que dicha concesión habrá sido otorgada con el mismo término que la del servicio público. Así lo impone hoy el artículo 125.3 del Reglamento del Dominio Público Hidráulico (aprobado por Real Decreto 849/1986, de 11 de abril), por cuya virtud «en las concesiones para el servicio público de abastecimiento, prestado por las Corporaciones Locales en régimen de gestión indirecta, la duración de la concesión no podrá exceder de la fijada para el régimen de gestión.»

Pero aunque así no fuera, y supuesto además que el concesionario demanial fuera el gestor indirecto del servicio y no el propio Ayuntamiento ${ }^{31}$, parece asimismo lógico entender que procedería la revisión de la concesión demanial, que es un negocio final (para un determinado uso para cuyo ejercicio ya carece su beneficiario de título), pues lo contrario impediría al Ayuntamiento el ejercicio de su competencia en materia del servicio y, por tanto, violaría la lealtad institucional debida entre las diversas Administraciones públicas. Como ha afirmado el Tribunal Supremo, «la concesión del agua (...) por el órgano hidráulico competente es un hecho que, aunque indiscutible, en nada obstaculiza el ejercicio de la competencia municipal en virtud del sistema de competencias concurrentes, de todos conocido» ${ }^{32}$. Además del precepto citado en el párrafo anterior, varios son los indicios legales de esta vinculación de la concesión demanial a la existencia de título suficiente para el uso en que consiste el aprovechamiento, por lo demás evidente. De conformidad con lo dispuesto en

\footnotetext{
${ }^{31}$ Precisamente por los problemas que plantea esta hipótesis para la debida coherencia entre el uso del demanio concedido y la competencia sobre el servicio, EMBID IrUjo y MESTRE Delgado se inclinan por entender que la nueva LA impone de forma general la concesión a sujetos públicos, interpretación de la que discrepa GARCíA DE CocA (todos ellos, en las op. cit. en nota n. ${ }^{\circ}$ ).
}

32 STS de 5 de marzo de 1991, R.Ar. 1991\1973. 
el artículo 61.2 de la vigente Ley de Aguas, «el agua que se conceda quedará adscrita a los usos indicados en el título concesional, sin que pueda ser aplicada a otros distintos». Y en particular para las concesiones de aguas para el servicio de abastecimiento de poblaciones, el artículo 123 del citado Reglamento del Dominio Público Hidráulico dispone en su apartado $1 .^{\circ}$ que la solicitud de concesión sólo puede ser deducida «por el representante de la Corporación Local o de la persona jurídica que gestione el servicio».

El artículo 65.1.a) LA habilita, en consecuencia, para revisar la concesión «cuando de forma comprobada se hayan modificado los supuestos determinantes de su otorgamiento» y ello sin derecho a indemnización, de conformidad con lo dispuesto en el apartado 3 del mismo precepto. Cuestión distinta sería que se hubiera procedido al rescate del servicio antes del vencimiento del término de su concesión.

A la misma conclusión llegaríamos, en fin, aunque el prestador del servicio hubiera aportado al mismo unas aguas privadas conforme al régimen de la LA 1879 y reconvertidas en un «aprovechamiento temporal de aguas privadas» por acogimiento a lo dispuesto en la disposición transitoria $4 .^{a}$ LA, con los efectos de las disposiciones segunda y tercera a que aquélla remite.

A estos justos efectos, importa recordar que, si bien la Ley de Aguas de 1985 procedió a demanializar las aguas continentales, tanto superficiales como subterráneas renovables, así como también los acuíferos subterráneos a los efectos de los actos de disposición o de afección de los recursos hidráulicos (arts. 1.2 y 2 LA), sin embargo, estableció un régimen transitorio dirigido a conciliar dicha innovación con los derechos consolidados por los particulares sobre las aguas que tenían la consideración de privadas en el marco de la legislación precedente. Dicho régimen transitorio permitió a los titulares de dichas aguas optar por solicitar «inscribir [sus aprovechamientos] en el Registro de Aguas (...) a los efectos previstos en las disposiciones transitorias segunda y tercera» (disp. transit. 4. ${ }^{\mathrm{a}} \mathrm{LA}$ ), referidas respectivamente a las aguas privadas «procedentes de manantiales» y «procedentes de pozos o galerías de explotación» y que, una vez inscrito el derecho «como aprovechamiento temporal de aguas privadas», mandan a la Administración respetar dicho régimen por un plazo máximo de cincuenta años, transcurrido el cual se extingue dicho derecho de «aprovechamiento temporal»si bien se reconoce a su titular, si siguiera utilizando los caudales en virtud de título legítimo, un derecho preferente para la obtención de la correspondiente concesión administrativa, con aplicación, pues, claramente ya del régimen demanial implantado por la Ley. 
La alternativa para los titulares de las aguas privadas era mantener sus derechos preexistentes conforme al régimen legal precedente («... mantendrán su titularidad en la misma forma que hasta ahora...», dicen las disp. transit. 2. ${ }^{\mathrm{a}}$ y $3 .^{\mathrm{a}}$, ambas en su apartado segundo), lo que ha sido interpretado como un limbo jurídico que la Ley ha querido desincentivar al negarles «la protección administrativa que se deriva de la inscripción en el Registro de Aguas», críptico inciso — y polémico- cuya interpretación no es de este lugar.

Esto supuesto, se podría pretender que el titular del aprovechamiento temporal de aguas privadas debería ser mantenido en su derecho durante todo el plazo transitorio de la Ley de Aguas, de forma que su extinción antes del vencimiento del mismo constituiría una expropiación del derecho y sólo procedería mediante indemnización.

Ahora bien, dicha conclusión, a fuer de ser errónea, se apoya en una única perspectiva: la de los bienes objeto del derecho, sin consideración, pues, de la perspectiva aquí concurrente (y prevalente, como ha quedado ya dicho) de la actividad o el servicio a que se hallan afectos dichos bienes. Desde esta segunda perspectiva, ¿modifica dicha conclusión la circunstancia de que el aprovechamiento de que hablamos constituya un servicio público y que el título para la gestión indirecta de dicho servicio ya ha decaído, habiéndose extinguido la relación subsistente con la concesionaria?

Parece plantearse un conflicto de normas entre la legislación transitoria de aguas y la legislación de servicios públicos (en particular, su principio de continuidad del servicio). Y, sin embargo, tal conflicto es a mi juicio más aparente que real, pues una interpretación teleológica del mencionado régimen transitorio de la legislación de aguas debe llevar a concluir que con el mismo se ha querido mantener temporalmente por el plazo de los 50 años no cualesquiera derechos de aprovechamiento de aguas que eran hasta ahora privadas, sino cabalmente los derechos constituidos por un título perenne (por ejemplo, el riego de una finca de la propiedad de su titular), pero no aquéllos amparados en un título - ya sea privado, ya administrativo - asimismo sometido a término, como ocurre con el habilitante para la gestión de un servicio público esencial y, por tanto, cuyo titular (el del servicio en que consiste cabalmente el aprovechamiento) no es la concesionaria sino la Administración concedente. De ahí que la disposición transitoria $2 .{ }^{a}$ LA imponga respetar el aprovechamiento temporal «por un plazo máximo de cincuenta años» (la cursiva es mía), pero que podrá ser inferior cuando lo sea la duración del título legitimador del aprovechamiento. 
Nótese que quien se acoge voluntariamente a esta alternativa del régimen transitorio está mutando la naturaleza de su derecho, que ya no es más de dominio o propiedad sobre las aguas aunque sí lo fuera en origen, sino al «aprovechamiento temporal» de las mismas. En su redacción original de 1985, el inciso final del apartado $1 .^{\circ}$ de estas dos disposiciones transitorias dejaba testimonio expreso de que la opción que nos ocupa constituía en efecto una «transformación del derecho»: de un derecho de dominio a uno de aprovechamiento de aguas.

La diferencia entre dominio y aprovechamiento no sólo ha sido capital históricamente en el Derecho de aguas sino que, como ha recordado justamente Sebastián MARTín-RETORTILLO ${ }^{33}$, se expresaba ya «con una claridad meridiana» en la Exposición de Motivos de la Ley del ramo de 1866, en la que se lee que es «indispensable determinar los caracteres generales que separan y diferencian el aprovechamiento del dominio. Éste es un derecho absoluto e ilimitado sobre la cosa, que nos autoriza para hacer libremente de ella el uso que nos plazca, siempre que no lastimemos el derecho de otro [...]. El aprovechamiento, por el contrario, es un derecho limitado, sujeto a las condiciones impuestas por quien lo concede, y que no autoriza para abusar, sino sólo para usar en la forma y para el objeto concedido.» (La cursiva es mía). Si bien es sabido que hoy ya no cabe sostener el carácter absoluto e ilimitado del dominio en los términos reproducidos, pues la propiedad es un derecho estatutario y delimitado por su función social, la distinción sigue siendo necesaria y permite comprender mejor la temporalidad del derecho al «aprovechamiento temporal» arbitrado por el régimen transitorio de la nueva Ley de Aguas, que no se corresponde con un derecho de propiedad, por naturaleza indefinido, por más que la Ley siga calificando a las aguas que tiene por objeto como «privadas» ${ }^{34}$.

El propio Tribunal Constitucional parece confirmar esta interpretación, aunque sea incidentalmente, en las Sentencias en las que ha sancionado la constitucionalidad del régimen transitorio de la Ley de Aguas del Estado (STC 227/1988, de 29 de noviembre, F.J. 8..$^{\circ}$ y la de la Comunidad Autó-

\footnotetext{
${ }^{33}$ Derecho de aguas, cit., p. 258. El autor aplica esta diferenciación en sintonía con lo que aquí se afirma, pues considera que el derecho transitorio de que hablamos no es ya de propiedad, sino de aprovechamiento (ibidem, p. 150).

${ }^{34}$ Por el contrario, Miguel Sánchez Morón ha sostenido, sobre esta base, que el derecho sigue siendo de propiedad, si bien comparte lo afirmado sobre su mutación: «Es un derecho de propiedad, pero se trata de una propiedad especial, delimitada estrictamente en su contenido. Hay una novación del derecho originario o adquirido que se produce ex lege cuando sus titulares ejercitan esta opción» («Transformación y pérdida futura o limitación del contenido de la propiedad privada de las aguas: sobre algunos aspectos del régimen transitorio de la nueva Ley de Aguas», Revista Española de Derecho Administrativo, n. ${ }^{\circ} 46$, abril-junio 1985, p. 183).
} 
noma de las Islas Canarias (STC 17/1990, de 7 de febrero, F.J. 14. ${ }^{\circ}$ ), que es «sustancialmente idéntico» al anterior. En ambos casos, el Alto Tribunal entiende que el legislador ha compatibilizado la demanialización de las aguas con el mantenimiento de los derechos preexistentes, para lo que la primera de las Sentencias aludidas entiende que la inscripción de un derecho como aprovechamiento temporal de aguas privada» conlleva la «transformación» del derecho y la segunda, más explícita a este propósito, la califica como una «reacomodación de esos derechos al nuevo régimen jurídico establecido (...), transformándose el título originario en una concesión administrativa» (la cursiva es mía). Esta última calificación como concesión puede resultar equívoca desde el momento en que el derecho de aprovechamiento temporal sobre las aguas se adquiere por disposición legal mediante su sola inscripción como tal, aspecto éste que invita más bien a considerarlo como un derecho sui generis de uso privativo aunque equiparable en lo demás al que se constituye por concesión, pero es ciertamente expresiva de la mutación del derecho de que se trata en el sentido aquí defendido de la limitación tanto de su contenido como de su duración.

Esto supuesto, la duración del derecho de aprovechamiento no puede prolongarse más allá que la del título habilitante de la gestión del servicio en que consiste o a que está afectado dicho aprovechamiento, cuando sea el caso. No parece, desde luego, que las disposiciones transitorias de la nueva Ley puedan tener por efecto una quiebra de la continuidad lógica entre el aprovechamiento y su destino cuando éste sea un servicio público. No es ese su objeto, sino más bien al contrario: facilitar la reconstrucción de dicha continuidad lógica sin causar una ablación indemnizable de los derechos consolidados conforme al régimen anterior.

Pues bien, si el aprovechamiento de que hablamos se constituye para prestar un servicio público (el mismo acto de inscripción registral del aprovechamiento, de ser el caso, debería haber advertido su afección en concreto al servicio de abastecimiento de aguas del Municipio de que se trate), no pueden ignorarse las reglas legales de dicho servicio en la interpretación de las disposiciones transitorias de la Ley de Aguas: tales reglas sólo mandan a la Administración hidráulica «respetar» el régimen de «aprovechamiento temporal de aguas privadas», pero no mantener a quien fuera originalmente su titular más allá de la vigencia de su título.

Cuanto digo se ilustra con claridad, mutatis mutandi, con un ejemplo de títulos temporales de Derecho privado: según las disposiciones transitorias 2. ${ }^{\mathrm{a}}$ y $3{ }^{\mathrm{a}} \mathrm{LA}$, quienes pueden acreditar ante la Administración hidráulica su derecho para su inclusión en el Registro de Aguas como aprovechamiento 
temporal de aguas privadas son «los titulares de algún derecho» y no necesariamente los propietarios del agua conforme a la legislación derogada. Pues bien, si quien ejerciese tal opción fuese un cesionario, usufructuario o arrendatario del agua, por ejemplo, es decir, quien disfruta del aprovechamiento en virtud de un título jurídico-privado limitado temporalmente, es evidente que no vería prorrogado ex lege el mismo hasta cumplirse los cincuenta años previstos en tales disposiciones.

Cuestión distinta habría sido que la empresa fuera titular de un aprovechamiento distinto (por ejemplo, para riego u otros usos) y la Administración acordase ahora ex novo su desviación o destino al abastecimiento de la población: en tal caso, procedería desde luego la expropiación del derecho, mediante indemnización de su valor, ya fuera éste jurídico-privado conforme a la legislación anterior (aprovechamiento de aguas privadas ${ }^{35}$ ) o jurídico-público de origen concesional conforme a la nueva legislación de aguas (vid. artículo 60.2 LA). Pero para ello se precisa la existencia de un derecho subjetivo de contenido ajeno al servicio, pues la reversión del servicio a que está afecto el bien objeto del derecho habilita sin más para revisar la concesión de dicho bien y, en consecuencia, para extinguir el derecho en sí (en tanto que derecho de contenido coextenso con la actividad revertida).

\section{LA NATURALEZA Y LOS EFECTOS DE LA CADUCIDAD DE LA CONCESIÓN A SU VENCIMIENTO}

La doctrina más autorizada venía afirmando tradicionalmente la naturaleza de «negocio fijo» de las concesiones, de forma que caducan a su vencimiento, lo que, aunque constituye un efecto ex lege, hace sin embargo depender su efectividad (conditio iuris) de la declaración expresa de la Administración ${ }^{36}$. El Tribunal Supremo ha acogido sin fisuras esta doctrina en su Sentencia ya citada más atrás de 14 de julio de 1981 (R.Ar. 198113484):

«la concesión, toda concesión, ha de ser incardinada en la categoría conceptual de «negocio fijo», o «negocio de término esencial», lo que quiere decir que esta figura jurídica no es concebible en una dimensión temporal indefinida y que, más pronto o más tarde, la concesión ha de caducar; constituyendo la caducidad un efecto «ex lege», propio de los «negocios fijos», aunque sometido, en principio, para su plena

\footnotetext{
35 Vid., por ejemplo, al respecto la STS de 31 de enero de 2000, R.Ar. 20001376.

${ }^{36}$ Eduardo GarCía DE EnTERRÍA, «El problema de la caducidad de las concesiones de aguas públicas ...», cit., pp. 270-271.
} 
DEMANIO, OBRA PÚBLICA Y SERVICIO PÚBLICO EN EL ABASTECIMIENTO DE AGUAS A LA POBLACIÓN...

efectividad, al presupuesto («conditio iuris») de la declaración expresa de la Administración; declaración que se limita a constatar la producción del hecho extintivo de la concesión, y a manifestarlo, para así eliminar toda duda al respecto, y suprimir el equívoco de una situación de apariencia, de una concesión en realidad caducada, pero hasta entonces no declarada.»

Quiere esto decir que la extinción del contrato y la reversión del servicio a su Administración titular se producen ipso iure, por imperio de la Ley, al término de su duración. Lo que no quita para que:

1. ${ }^{\circ}$ Por razones evidentes de seguridad jurídica, para hacer valer dicho efecto extintivo, se exija la tramitación de un procedimiento conducente a una resolución que, sin embargo, será meramente declarati$v a$ de la extinción y, en cuanto tal, un acto debido de la Administración.

La reversión no es sino el nombre propio que recibe en los contratos de gestión de servicios públicos la extinción por cumplimiento del contrato (art. 109 LCAP), cuya «constatación», dice nuestra Ley de Contratos, «exigirá por parte de la Administración un acto formal y positivo» (art. 110.2).

2. ${ }^{\circ}$ El gestor del servicio pueda mantenerse entre tanto en la prestación del mismo, pero ya no porque siga siendo eficaz o pueda entenderse implícitamente rehabilitado su título habilitante, sino sólo de forma provisional y excepcional, a precario y por razones improrrogables de orden público, como es la continuidad del servicio público. No se trata, pues, en propiedad de una prórroga de la concesión, que ya es imposible una vez vencido el plazo legal máximo de su otorgamiento (art. 157 LCAP: «...sin que pueda exceder el plazo total, incluidas las prórrogas, de los siguientes periodos: ...»; la cursiva es mía).

De la unión de lo expuesto en los dos ordinales precedentes se sigue que una cosa es que el gestor indirecto del servicio pueda mantenerse provisionalmente en la prestación del mismo mientras no se declare la extinción de la concesión y otra bien distinta que la Administración pueda abstenerse lícitamente de incoar y resolver el expediente a ello tendente. La competencia administrativa es en general irrenunciable, como proclama hoy el artículo 12.1 de la Ley 30/1992, de 26 de noviembre, sobre Régimen Jurídico de las Administraciones Públicas y Procedimiento Administrativo Común. Sabemos ya que es de la competencia municipal el servicio de abastecimiento de aguas y, más concretamente, lo es de su Pleno la aprobación de su forma de gestión [art. 22.2.f) LBRL] y del Alcalde todo 
lo relativo a su concesión hasta ciertos límites [art. 21.1.ñ) LBRL], y que se trata además de un servicio público de prestación obligatoria en todos los Municipios [art. 26.1.a) LBRL], lo que refuerza la interpretación sostenida sobre la improrrogabilidad del ejercicio de las potestades referidas a su forma de gestión, pues el prestador del servicio a precario después de la caducidad de su concesión ya no se encuentra obligado por contrato ninguno.

Por lo demás, que la Administración municipal deba incoar de oficio el procedimiento conducente a la declaración de caducidad de la concesión no empece para que también pueda instarla cualquier empresa competidora de la gestora del servicio.

El Reglamento de Servicios de las Corporaciones Locales ya prevé en sus artículos 117 y siguientes que el procedimiento de concesión de un servicio público pueda ser iniciado a instancia del particular que lo «solicitare por su propia iniciativa». Aunque tal hipótesis sólo se plantea para los servicios de nuevo establecimiento, pone de relieve la legitimación de las empresas del sector económico correspondiente para solicitar el establecimiento y prestación de servicios públicos. Por vía de analogía, pues, puede también sostenerse su legitimación para solicitar la declaración de la reversión de un servicio por caducidad de su concesión, como condición sine qua non (del mismo modo que lo es, en el supuesto anterior, el establecimiento del servicio) para poder obtener su concesión.

En cualquier caso, no es preciso acudir a la analogía para justificar dicha legitimación activa. En primer lugar, porque la jurisprudencia había sentado hace ya décadas una doctrina según la cual el que dio en llamar «interés profesional» o «interés competitivo» constituía un interés directo en el asunto, por aquel entonces requerido para la legitimación ad causam $^{37}$. Y aunque así no fuera, sabido es, en segundo lugar, que la Constitución ha producido posteriormente un poderoso efecto dilatador de dicha legitima-

\footnotetext{
${ }^{37}$ Dicha doctrina se aplicó, por ejemplo, para entender que, en un procedimiento de prórroga del fletamento de un buque utilizado por una naviera que explotaba una línea de transporte marítimo regular, debía tenerse a otra compañía titular de otra línea directamente competidora de aquélla por legitimada para impugnar el acuerdo de la prórroga tanto en vía administrativa como judicial, conforme «al criterio espiritualista y abierto que debe presidir la interpretación de «interés directo», máxime después de la Constitución que en su artículo 24 proclama como derecho fundamental el de obtener la tutela judicial» (STS de 8 de marzo de 1985, R.Ar. 1985\1147); que el titular de una empresa funeraria tiene un interés directo en que no se concedan autorizaciones de apertura a otras empresas del ramo (STS de 21 de junio de 1985, R.Ar. 1985\4912); o que el solicitante de una autorización para la prestación de un servicio público regular de viajeros por carretera tiene asimismo interés directo en la declaración de caducidad de la concesión de que es titular otra empresa (STS de 6 de mayo de 1993, R.Ar. 199313395).
} 
ción, efecto que se dejó sentir primero en la interpretación judicial y que hoy se ha trasladado a la legislación positiva, que ha sustituido el viejo concepto del «interés directo» por el mucho más abierto del «interés legítimo». Éste es ya el único interés requerido, en efecto, tanto para poder iniciar un procedimiento administrativo [art. 31.1.a) LRJPAC] como para ejercer una acción en el orden jurisdiccional contencioso-administrativo [art. 19.1.a) de la Ley 29/1998, de 13 de junio, reguladora de la Jurisdicción ContenciosoAdministrativa]. Nuestro Tribunal Supremo tiene una aquilatada doctrina en la interpretación de este concepto del «interés legítimo» ${ }^{38}$.

No puede caber duda de que una empresa que tenga por objeto el abastecimiento de aguas y sea directa competidora de la concesionaria de dicho servicio en un Municipio, comparte con ella — parafraseando a la jurisprudencia aludida - el ser «destinataria de una regulación sectorial» y, por ende, «titular de un interés propio» en la forma de prestación del servicio, que va más allá del interés de los ciudadanos en general, de forma que el mantenimiento irregular a su competidora en la gestión de dicho servicio pese al vencimiento de su título le origina un «perjuicio indirecto» que la legitima para interesar la declaración de caducidad de dicho título, lo que le permitiría participar en la licitación por la adjudicación de una nueva concesión y, de obtenerla, «conseguir un determinado beneficio material o jurídico». Este «interés competitivo» en el asunto constituye ciertamente un interés legítimo y, por tanto, legitima a la compañía a los efectos que nos ocupan.

\footnotetext{
${ }^{38}$ Dicha jurisprudencia se resume con precisión y claridad en la STS de 4 de febrero de 2002 (R.Ar. 200212913), según la cual «Como ha tenido ocasión de reiterar este Tribunal, la legitimación, como aptitud para deducir una pretensión y presupuesto de admisibilidad del proceso, ha de reconocerse para la defensa judicial de cualquier derecho o interés legítimo (art. 24.1 CE), entendiendo que éste concurre siempre que el demandante pueda, con la obtención de lo pretendido, estar en situación de conseguir un determinado beneficio material o jurídico —-más allá de la observancia de la mera legalidad propia de la acción popular- o que del mantenimiento de la situación creada por el acto judicialmente combatido le origine un perjuicio, aunque sea indirecto. $\mathrm{O}$, en otros términos, como entiende la más moderna jurisprudencia, el «interés legítimo» es un concepto más amplio que el interés personal y directo al que se refería el artículo 28.1 a) LJCA, debiendo reconocerse a aquellas personas que, por la situación objetiva en que se encuentran, por una circunstancia de carácter personal o por ser los destinatarios de una regulación sectorial, son titulares de un interés propio, distinto del de los demás ciudadanos en que las Administraciones actúen de acuerdo con el ordenamiento jurídico (SSTS 4 de marzo, 8 de abril [R.Ar. 1994l3016], 9 de mayo [R.Ar. 199415304] y 26 de septiembre de 1994 [R.Ar. 199417339], por sólo citar algunas de las más recientes).»
} 